Acta Regionalia et Environmentalica 2

Nitra, Slovaca Universitas Agriculturae Nitriae, 2019, pp. 38-44

\title{
SEASONS OF DROUGHT IN SLOVAKIA DURING THE PERIOD FROM 1957 TO 2016
}

\author{
Veronika ZUZULOVÁ*, Matej ŽILINSKÝ, Bernard ŠIŠKA \\ Slovak University of Agriculture in Nitra, Slovakia
}

\begin{abstract}
The aim of the paper was to describe the occurrence of dry seasons in Slovakia. Dry seasons in the period from 1957 to 2016 were determined according to the monthly Palmer Drought Severity Index (PDSI). For this purpose, ten sites based on limit climatic parameters were chosen - Bratislava, Pieštany, Hurbanovo, Čadca, Sliač, Bol'kovce, Poprad, Košice, Milhostov, and Kamenica nad Cirochou. The results showed the alternation of dry and wet episodes and the variability of weather not only over time, but also over space. The analysis of linear trends showed that the arid trend was identified on most sites (9 localities).
\end{abstract}

Keywords: drought, Plamer Drought Severity Index, climate change

The comprehensive definition of drought is unclear because many types of it exist, for instance meteorological, physiological, hydrological, soil - agricultural and socioeconomic drought. Generally, drought is a long-term occurring state of imbalance between precipitations and evaporation when evaporation is higher than precipitations which are presented by negative variation of their average value in a certain area (EPA, 2016). Drought is one of the most dangerous phenomena that can have a serious impact on economics (mainly in agricultural sector), as well as on social and natural sphere (White, 2000).

The frequency of drought and its severity has been more intensive since 1950 in Europe and also in Slovakia (Spinoni et al., 2015). Thus, analysis of occurrence and recognition of drought during past periods is necessary for proposal and implementation of adaptations to this phenomenon nowadays. The PDSI (Palmer's Drought Severity Index) quantifies the meteorological drought based on variation in average precipitations, while precipitations and temperature are taken into account and drought is evaluated over a longterm period (Štastný, Turňa, 2013). There are many indices that represent local conditions in the world, for example, the PDSI is used in the USA, the RDDI in Australia, the Z-index in China, and the SPI in India (Vinit, 2015). The PDSI is a suitable indicator for determining the severity of drought in Slovakia, especially if a larger amount of reference locations is selected for comparison of the differences between them (Litschmann et al., 2001).

The aim of the paper is to determine the occurrence and severity of drought in the territory of the Slovak Republic between 1957 and 2016 on the basis of measured meteorological elements and provide a basis for the proposal of adaptations to climate change in the country. Evaluation of historical data and assessment of significant drought periods are some of the main components for the conception of drought risk reduction in the Guidelines for Drought Management Plans (Fatulová, 2015).

\section{Material and methods}

Identification of dry seasons was realized by calculations of the Palmer Drought Severity Index (Palmer, 1965). The index is standardized for different regions and different time series, so it can be used for assessment of drought in the localities with various climate conditions (Dunkel, 2009). The method involves not only climatic, but also pedological characteristics of the region. The calculation was realized by the program, which was developed by Tom Heddinghaus from the University of Nebraska-Lincoln in 2003. Input data include monthly precipitation totals, monthly average air temperature, average air temperature for the whole period, latitudes of the sites and available water capacity. Climatic data were provided by the Slovak Hydrometeorological Institute and pedological data from the Soil Science and Conservation Research Institute in Bratislava.

Ten sites were chosen for evaluation of drought in Slovakia according to limited climatic parameters: Bratislava, Pieštany, Hurbanovo, Čadca, Sliač, Bol'kovce, Poprad, Košice, Milhostov, and Kamenica nad Cirochou (Fig. 1).

The drought variability was characterized during the 60-year time series from 1957 to 2016 . We created charts for each site from the output values of the PDSI. Dry seasons were identified as those with values $\leq-1.00$ and also at least one month of the season in the category moderate drought $(-2.00$ to -2.99$)$ (Žalud et al., 2006). The linear trend was added into the charts for determining the character of the period on each site.

Contact address: Ing. Veronika Zuzulová, PhD., Department of Ecology, Faculty of European Studies and Regional Development, Slovak University of Agriculture in Nitra, Mariánska 10, 94901 Nitra, phone: +421 37641 5636, e-mail: xzuzulova@uniag.sk 


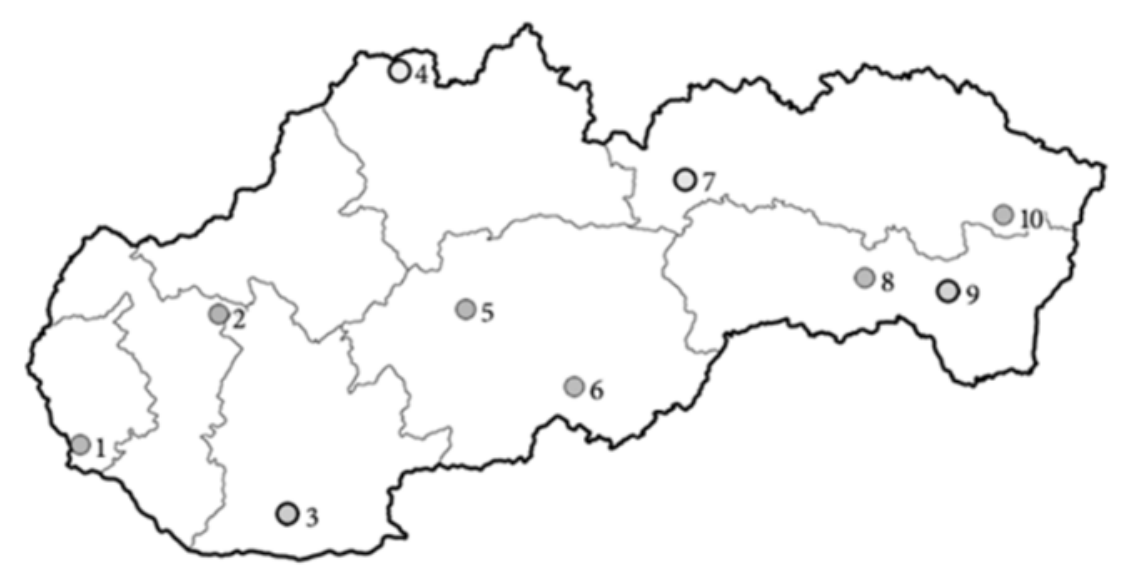

Figure 1 The sites selected for drought assessment

1 - Bratislava, 2 - Pieštany, 3 - Hurbanovo, 4 - Čadca, 5 - Sliač, 6 - Bolkovce, 7 - Poprad, 8 - Košice, 9 - Milhostov, 10 - Kamenica nad Cirochou

Table 1 Palmer's classification

\begin{tabular}{|l|c|}
\hline PDSI & Class \\
\hline \hline$\geq 4.00$ & extremely wet \\
\hline 3.00 to 3.99 & very wet \\
\hline 2.00 to 2.99 & moderately wet \\
\hline 1.00 to 1.99 & slightly wet \\
\hline 0.50 to 0.99 & incipient wet spell \\
\hline 0.49 to -0.49 & near normal \\
\hline-0.50 to -0.99 & incipient drought \\
\hline-1.00 to -1.99 & mild drought \\
\hline-2.00 to -2.99 & moderate drought \\
\hline-3.00 to -3.99 & severe drought \\
\hline$\leq-4.00$ & extreme drought \\
\hline
\end{tabular}

\section{Results and discussion}

Sixteen dry seasons were observed in Bratislava in the selected period: February - March 1959; September 1959 - May 1960; January - September
December 1997 - August 1998, when three months were extremely dry; May 2000 - July 2005 with extreme drought during 16 months; October 2006 August 2007, when last two months were extremely dry; May 2009 - March 2010; October 2011 - September 2012; December 2013 - June 2014; June 2015 - December 2016. The linear trend was decreasing, it means arid and it was caused by extremely wet and very wet months in the first half of the period and the onset of extremely dry months and more long-term dry seasons in the second half of the period (Fig. 2).

Sixteen seasons of drought were recorded in Pieštany: December 1963 - September 1964; June 1967 July 1968; September 1969 - January 1970; July 1971 - March 1972; June 1973 - July 1974; July 1977 - May 1979; November 1982 - January 1984; January 1989 - September 1993, when nineteen months were extremely dry; December 1996 - August 1998, when last three months were extremely dry; May 2000 - August 2001; October 2001 - June 2002; May - December 2003; October 2006 - August 2007, when three months were extremely dry; September 2011 - December 2012; December 2013 - September 2014; June 2015 - December 2016. The linear trend was decreasing, arid, caused by extremely wet months from 1965 to 1967 replaced by extremely dry months at the beginning of the second half of the period (Fig. 3).

We recorded 17 significant dry seasons in Hurbanovo during the period 1957-2016: January - August 1964; July 1967 - February 1969, when there was recorded one extremely dry month; July - November 1969; October 1970 - March 1972; October 1973 -

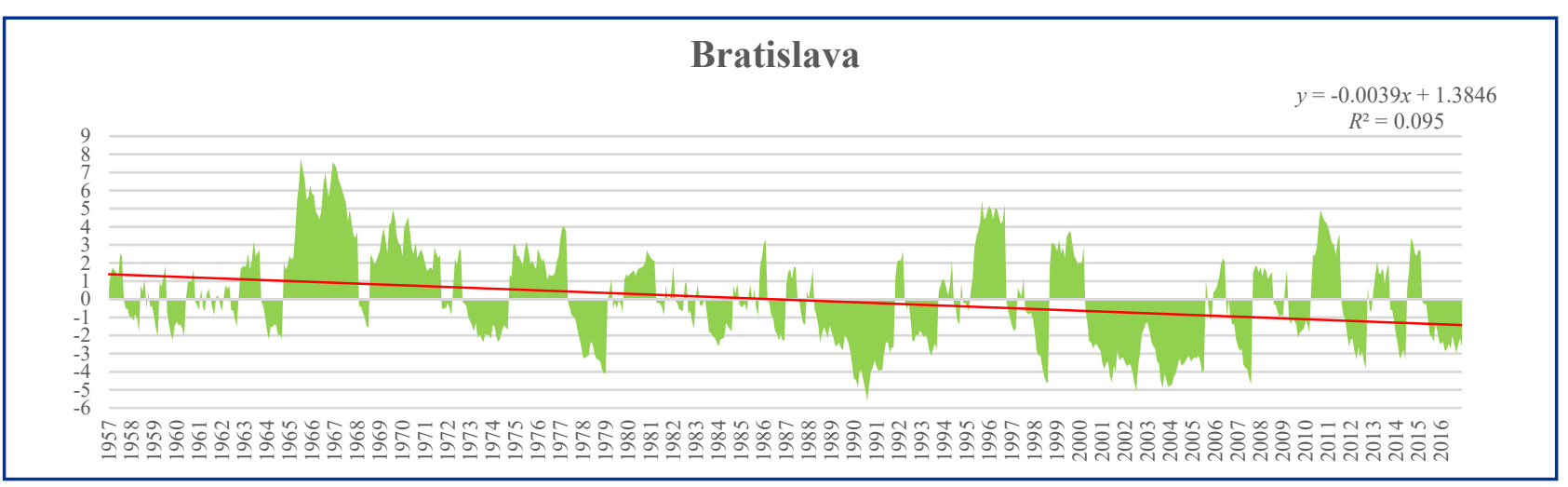

Figure 2 Monthly PDSI in Bratislava during the period from 1957 to 2016 


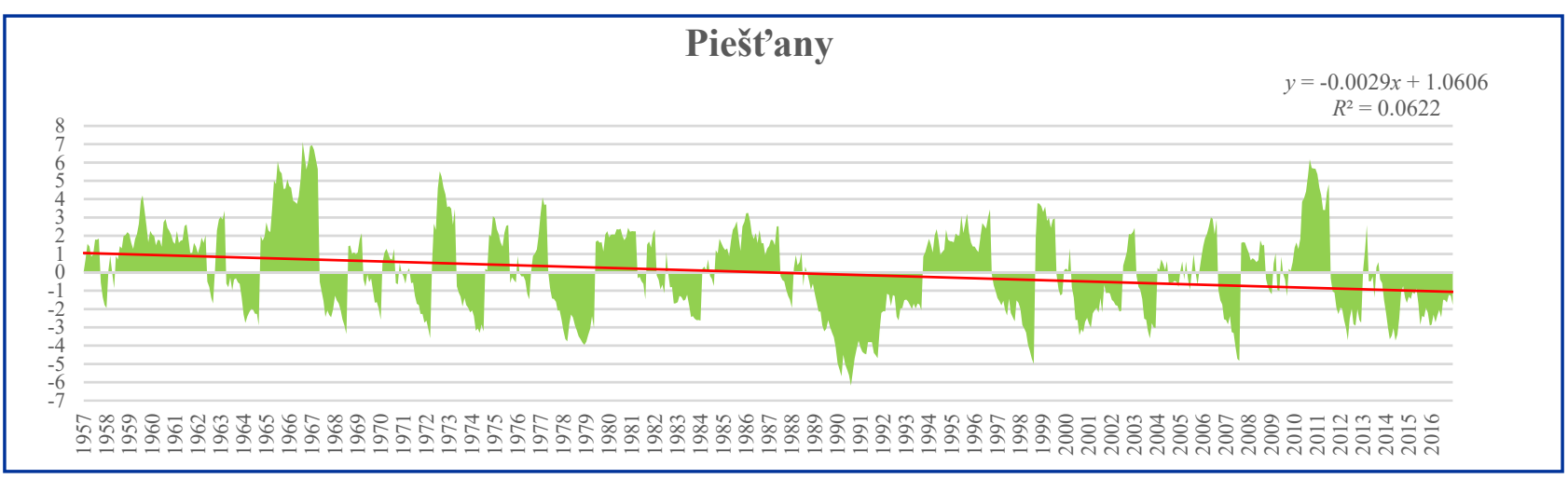

Figure 3 Monthly PDSI in Pieštany during the period from 1957 to 2016

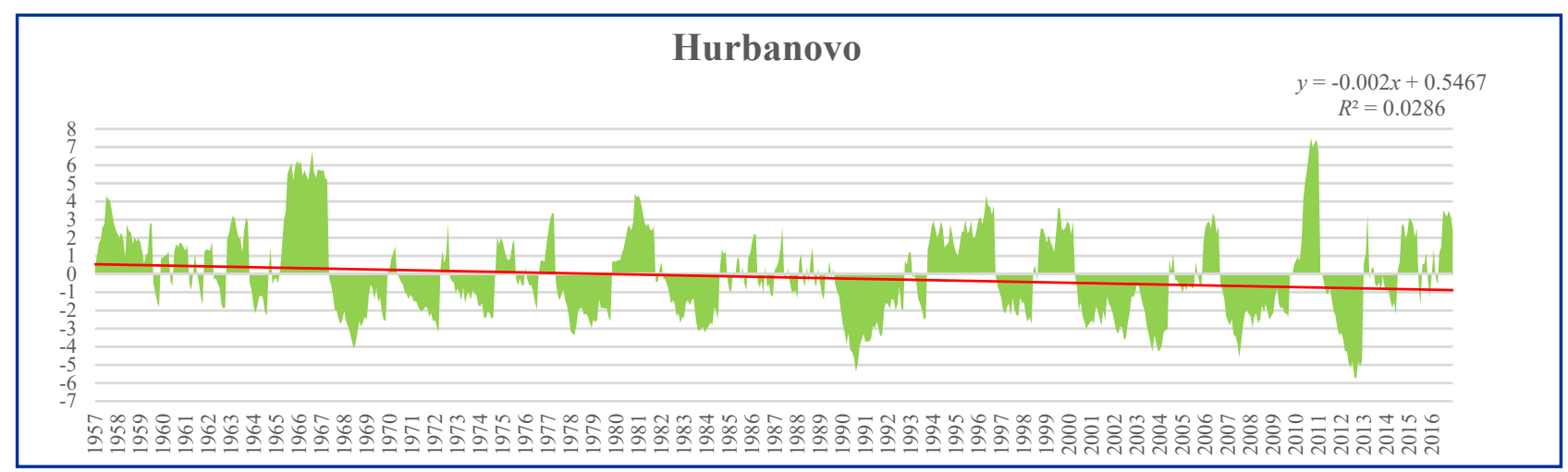

Figure 4 Monthly PDSI in Hurbanovo during the period from 1957 to 2016

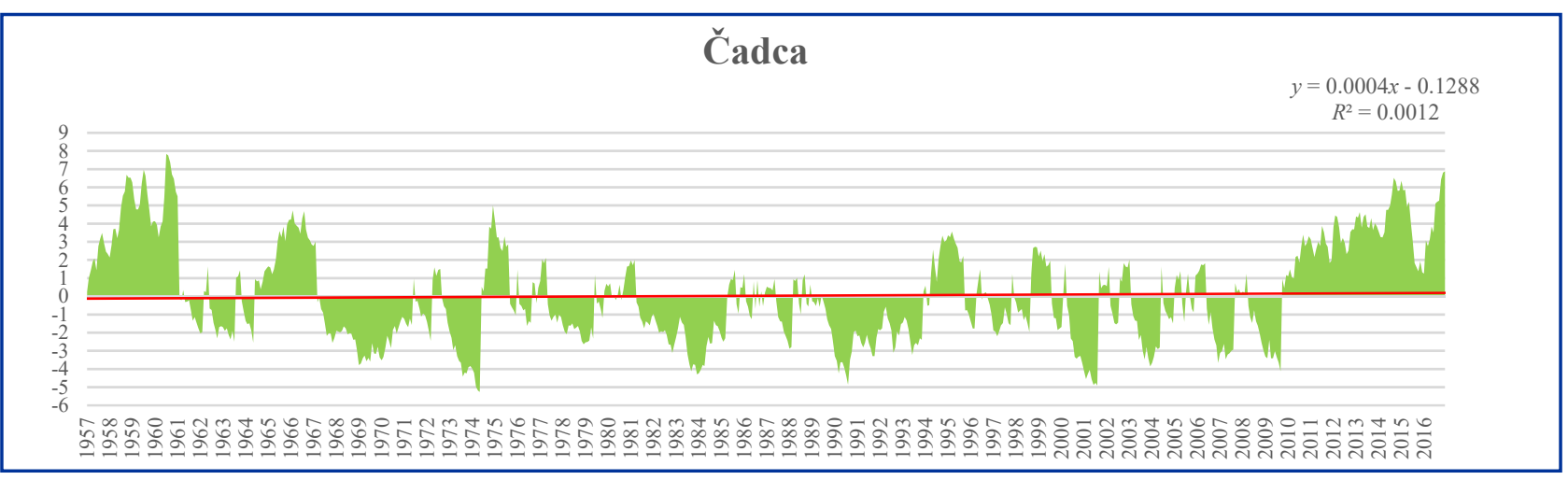

Figure 5 Monthly PDSI in Čadca during the period from 1957 to 2016

August 1974; October 1977 - October 1979; June 1982 July 1984; November 1989 - June 1992 with five extremely dry months; August - September 1992; May - September 1993; January 1997 - May 1998; June 2000 - November 2002; March 2003 - May 2004, when three extremely dry months were observed; November 2006 - February 2009 with one extremely dry month; April - September 2009; August 2011 - December 2012, when extreme drought was recorded during the last ten months and March - June 2014. Linear trend was arid, which was caused by two significant wet seasons at the beginning of the period and the subsequent onset of extreme drought in the second half of the period (Fig. 4).

Several case studies dealt with the assessment of drought in Hurbanovo. Patassiová et al. (2002) used the PDSI for the evaluation of drought period in the period 1961-
2000 and also considered linear trends during this period. They focused on the assessment of drought during April and May. They stated that the years 1968, 1974 and 1990 were very dry in April; the years 1984, 1974, 1978, 1997 and 1998 were moderately dry in April. In May, extreme drought values were recorded in 1990 and very dry values in 1968. Moderate dry years were in 1971, 1973, 1974, 1978, 1997 and 1998 in May. In comparison with our results, there are several differences. The PDSI values in April were extremely dry in 2012, as a longer time period was evaluated. Very dry years (April) were 1968, 1990, 1991, 2004 and 2007. Moderate dry years (April) were 1974, 1978, 1984, 1998, 2002 and 2008. The extreme drought in May was recorded in 1990 and also in 2012. Very dry May was not only in 1968, but also in 2004 and 2007. Moderately dry May was in 1971, 1974, 1991, 1998, 2001, 2002, 2003 and 2008. 
Litschmann et al. (2002) evaluated the drought during the period 1876-2000. The lowest monthly PDSI value (-6.0) was recorded in August 1990. In this article, the monthly PDSI value in August 1990 was -5.38, however, this is in the same category of extreme drought. The lowest PDSI value (-5.77) was recorded in September 2012.

The variability between the results of different studies using the PDSI method (although the same locations were evaluated) is probably due to the evaluation of different time series.

Sixteen seasons of drought were identified in Čadca during the selected period: September 1961 - February 1962; August 1962 - July 1963; January - May 1964; July 1967 - May 1971; December 1971 - March 1972; December 1972 - May 1974, when seven extremely dry months were recorded; June 1977 - May 1979; February 1982 - March 1985 with four extremely dry months; July 1987 - February 1988; September 1989 - March 1992, when three extremely dry months occurred in 1990; May 1992 - November 1993; December 1996 - June 1997; May 2000 - August 2001, in which eight months were classified as extreme drought; March 2003 - May 2004; September 2006 - August 2007; August 2008 - September 2009 with one extremely dry month, that was the last month from the season. The linear trend was increasing, humid, due to an extremely wet season from 2000 to 2014 and in 2016 (Fig. 5).

Sixteen dry seasons were observed in Sliač in the period: May 1958 - March 1959; August - October 1961; January May 1964; October 1967 - August 1968; May 1969 - January 1970; May 1973 - April 1974; February - August 1976; July 1983 - April 1984, when three months were extremely dry, July 1987 - August 1990, when four extremely dry months were observed in 1990; June 1992 - September 1993; June 2000 - June 2011; March 2003 - March 2004; October 2006 - February 2009 with three extremely dry months in 2008; April - September 2009; September 2011 - September 2012, when the last seven months were extremely dry; October 2013 - June 2014. The linear trend was arid, what was the result of an occurrence of significantly wet seasons at the beginning of the period and extreme drought that appeared mainly in the second half of the time series (Fig. 6).

Eighteen seasons of drought were recorded in Bolkovce in the period 1957 - 2016: June - October 1961; July October 1962; December 1963 - July 1964, when the last month of the season was extremely dry; December 1967 October 1968 with two extremely dry months; July 1971 March 1972; July 1973 - April 1974; June 1977 - March 1978; February 1982 - April 1984; August 1986 - April 1987; October 1988 - May 1989; September 1989 - March 1990; August 1992 - April 1994, when two extremely dry months occurred; November 1994 - February 1995; August October 2000; October 2001 - March 2005 with eight extremely dry months; October 2006 - May 2008, when July 2007 was classified as extremely dry; June - September 2009; September 2011 - September 2012 with six extremely dry months. The linear trend was decreasing, arid, due to extremely wet months at the beginning of the period and occurrence of seasons of extreme drought mainly from 1993 (Fig. 7).

There were eighteen seasons of drought observed in Poprad: July - October 1961; June 1963 - July 1964, when

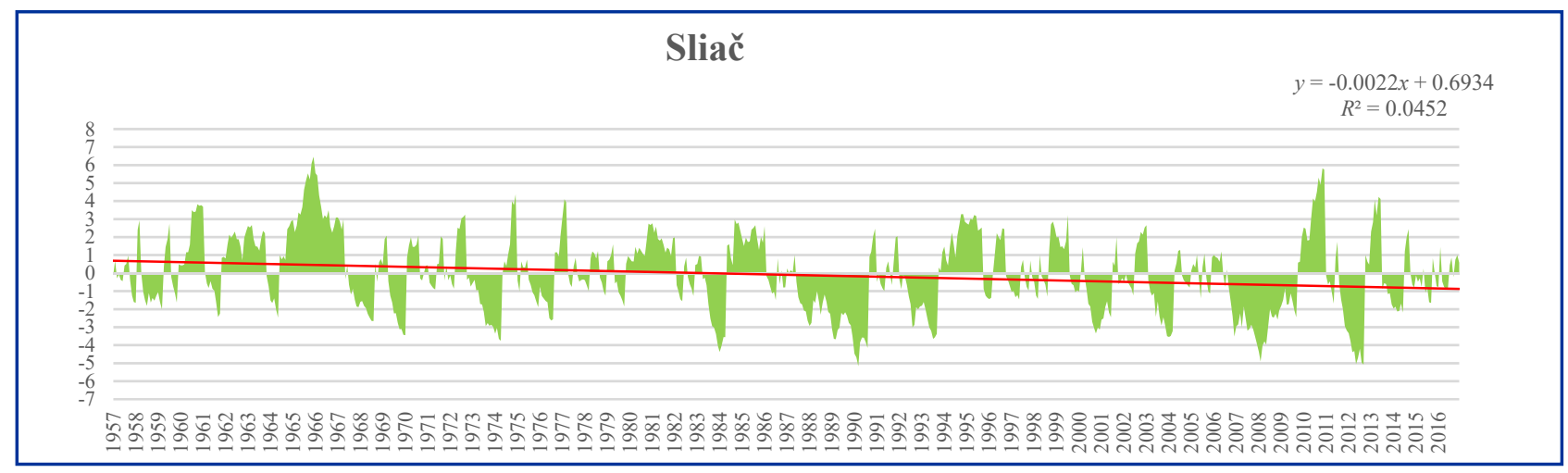

Figure 6 Monthly PDSI in Sliač during the period from 1957 to 2016

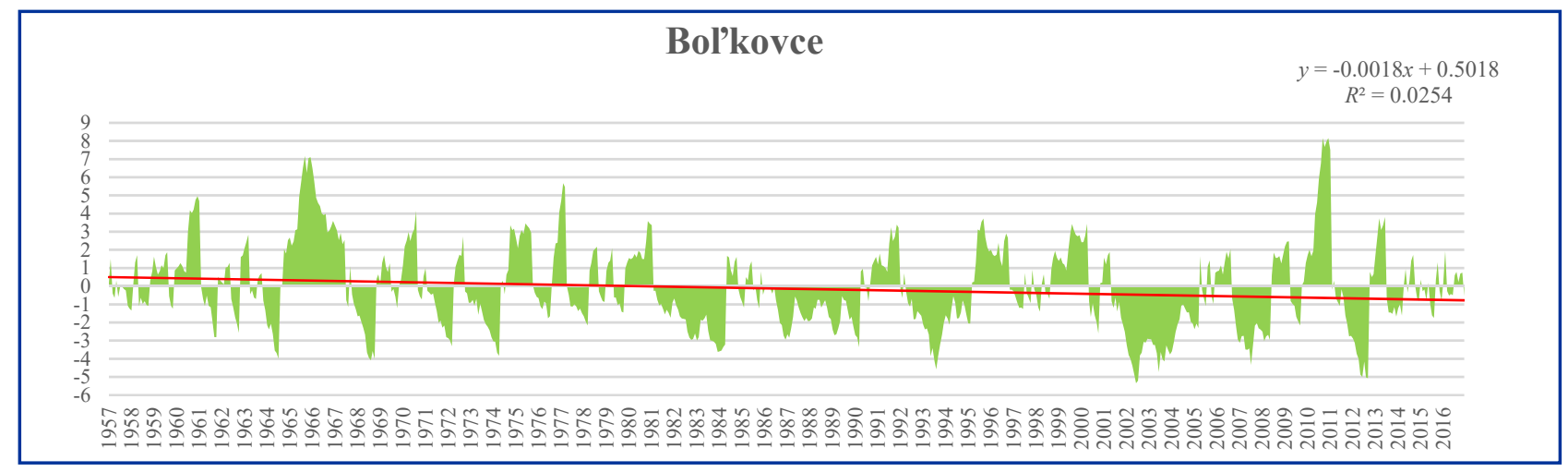

Figure 7 Monthly PDSI in Bolkovce during the period from 1957 to 2016 


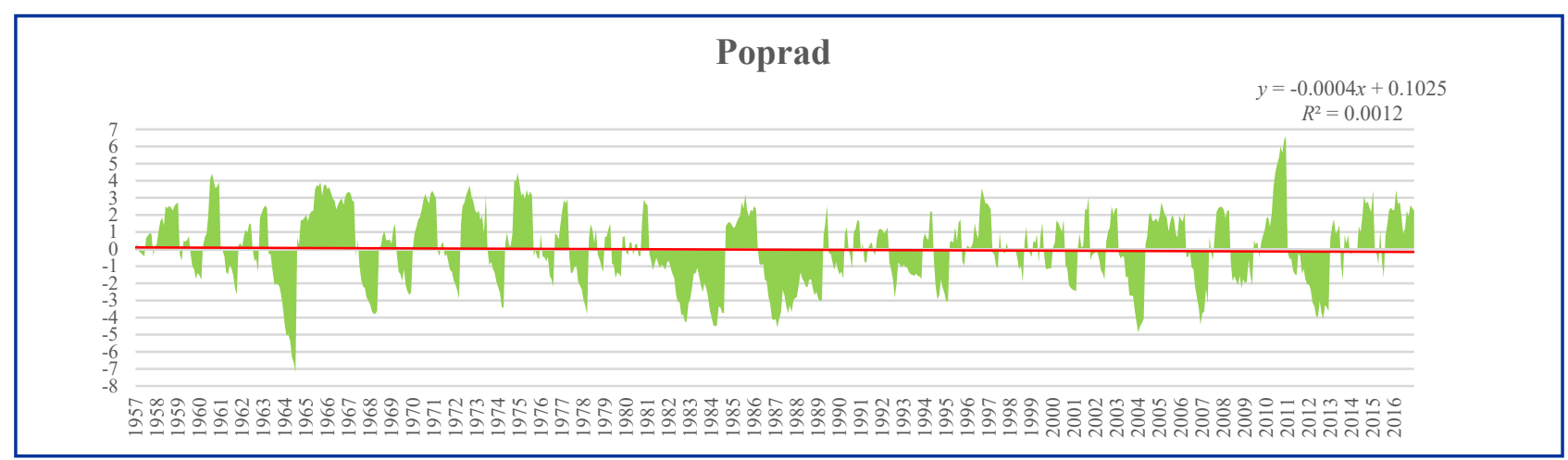

Figure 8 Monthly PDSI in Poprad during the period from 1957 to 2016

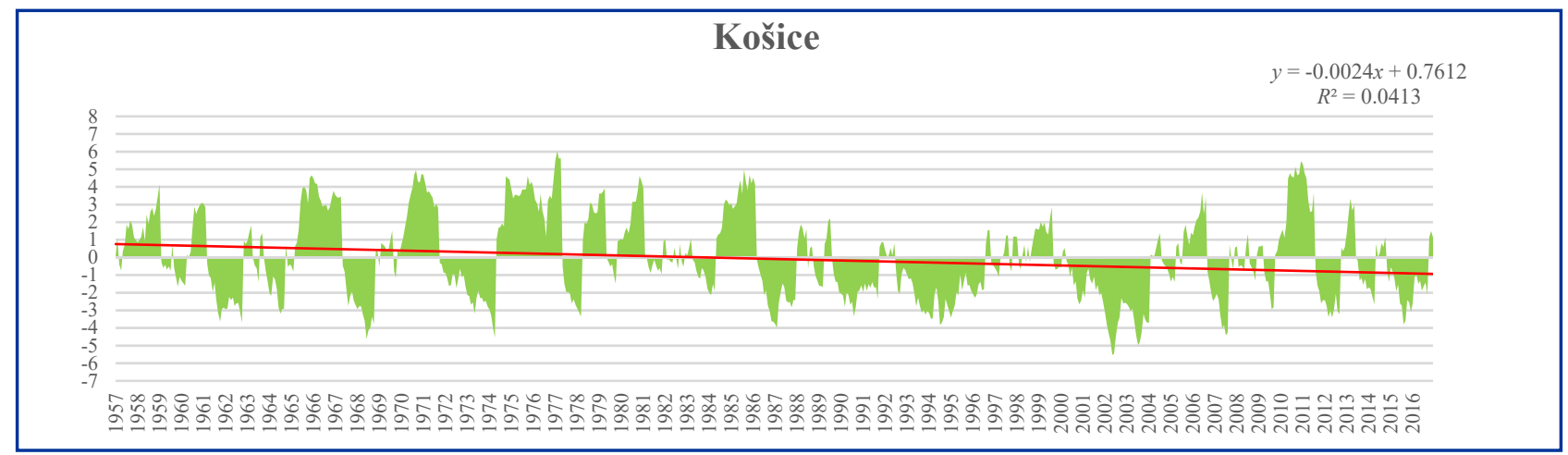

Figure 9 Monthly PDSI in Košice during the period from 1957 to 2016

last six months were extremely dry; August 1967 - May 1968; May - December 1969; October 1971 - March 1972; October 1973 - April 1974; June - August 1976; June 1977 - March 1978; February 1982 - August 1984, when five extremely dry months were recorded; July 1986 - March 1989 with five extremely dry months; June - September 1992; July 1994 February 1995; September 2000 - February 2001; June 2003 - April 2004, when last five months were classified as extremely dry; July 2006 - April 2007 with an extremely dry month; June 2008 - February 2009; April - May 2009; September 2011 - December 2012, when one extremely dry month was observed. The linear trend was arid, however, very slightly decreasing. The trend was balanced by the extremely wet year 2010 (Fig. 8).

Eighteen dry seasons were recorded in Košice during 1957-2016: April 1961 - October 1962; December 1963 September 1964; July 1967 - October 1968, when extreme drought was recorded during three months; October 1972 April 1974 with two extremely dry months; June 1977-March 1978; November 1983 - April 1984; June 1986 - December 1987, in which one extremely dry month was observed; October 1989 - September 1991; August - September 1992; January 1993 - May 1995; October 1995 - July 1996; August 2000 - February 2001; May 2001 - January 2004 with nine extremely dry months; October 2006 - August 2007, when three months were extremely dry; May - September 2009; September 2011 - September 2012; August 2013 - April 2014; March 2015 - September 2016. The linear trend was decreasing, arid, caused by significant wet seasons in the first half of the period and the onset of two long term droughts in the second half (Fig. 9).
Sixteen dry seasons were observed in Milhostov in the time series 1957-2016: April 1961 - October 1962; November 1963 - July 1964; August 1967 - December 1969; December 1971 - August 1972; December 1972 - April 1974 , when last three months were classified as extremely dry; September 1986 - November 1987; September 1989 - October 1991; January 1992 - February 1993; May 1993 - March 1994; July 1999 - June 2000; February - July 2002; May - August 2003; October 2006 - August 2007 with four extremely dry months; July - September 2009; October 2011 - September 2012, one extremely dry month was observed during the season; August 2013 - December 2016, when sixteen extremely dry months were recorded during 2015 and 2016. The linear trend was arid, which could be significantly influenced by an occurrence of very dry months in 2012, 2014 and 2015 and extremely dry months in 2012, 2015 and 2016 (Fig. 10).

In addition, the drought periods in Milhostov can be compared with the results of Tall and Gomboš (2011). They evaluated the series of years 1961-2007 and pointed to extreme drought years 1974 and 2007, when the monthly PDSI index hit the values -5.0 and -4.5 . Our results in Milhostov showed the extreme drought in 2007 from May to August with the lowest value (- 5.77) in August. The years 2015 and 2016 with the lowest value of -6.6 in September 2015 were also extremely dry.

Eighteen seasons of drought were recorded in Kamenica nad Cirochou during the time series: April 1961 - July 1964, when twenty-nine extremely dry months were observed; August 1967-July 1968; November 1971 - April 1972; August 1973 - April 1974; September 1975 - February 1976; June - 


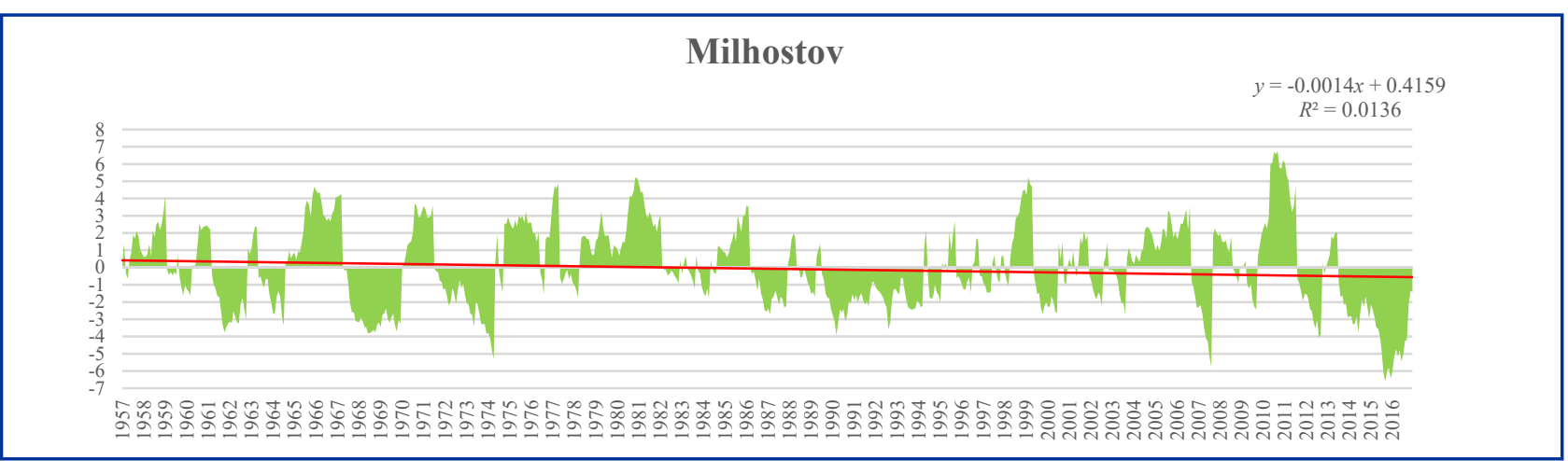

Figure 10 Monthly PDSI in Milhostov during the period from 1957 to 2016

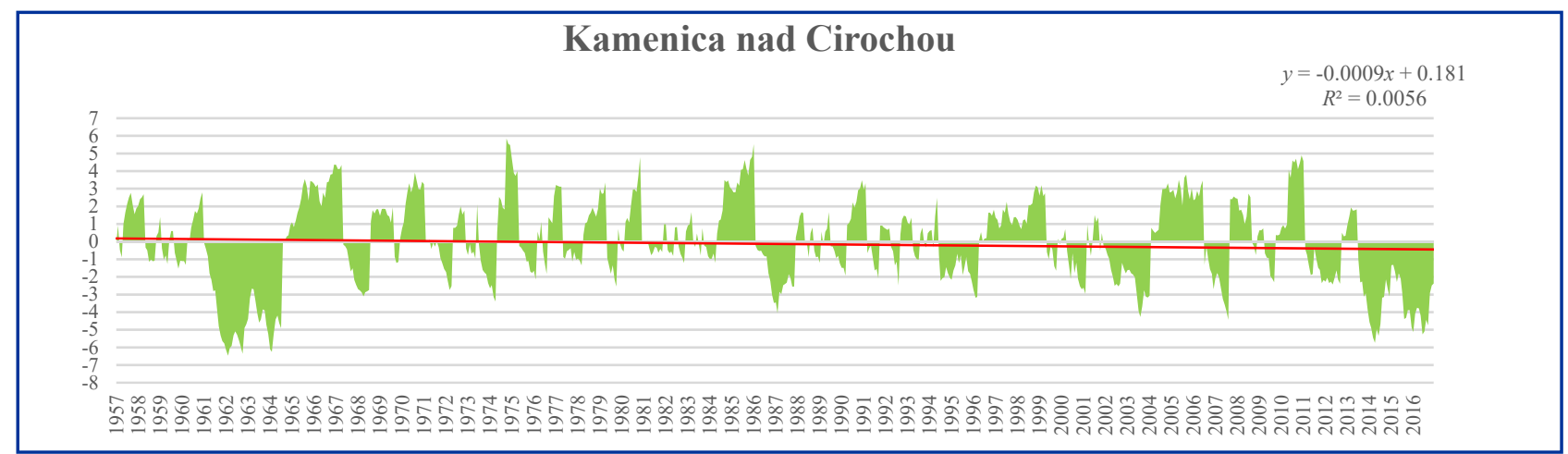

Figure 11 Monthly PDSI in Kamenica nad Cirochou during the period from 1957 to 2016

October 1979; September 1986 - November 1987 with one extremely dry month; July - September 1991; June - August 1992; July 1994 - March 1995; October 1995 - March 1996; May - June 2000; August 2000 - February 2001; April 2002 January 2004 with one extremely dry month; October 2006 - August 2007, when the last one was extremely dry; July - September 2009; September 2011 - September 2012; July 2013 - December 2016, when extreme drought was observed during seventeen months. The linear trend was decreasing, arid, due to balanced distribution of wet and dry months during the period with more significant occurrence of extremely dry months at the beginning (1961-1964) and at the end (2014-2014) of the period (Fig. 11).

The results of the drought assessment in Slovakia showed several years when drought affected all locations (1964, 1973, 1974, 1992, 2000, 2003, 2006, 2007, 2011 and 2012). The drought periods that occurred in the years were often parts of long-term droughts that lasted several years, but on the other hand, there were also those that lasted several months in given years. The results showed certain conformity with previous studies from other authors, for instance, Valach et al. (2014) analyzed the occurrence of drought in the Horné Požitavie region using the SPEI index (Vicente-Serrano et al., 2010) in the period 1966-2013. They stated in the paper that the periods of extreme drought were recorded from August 1967 to January 1968, August 1982 to June 1984, August 1989 to March 1994, May 1997 to May 1999, June 2000 to August 2001, May 2003 to May 2004, December 2006 to June 2008 and September 2011 to April 2013. Similarly, Vido et al. (2014) evaluated the same location and time period, however, they used the SPI index (McKee et al., 1993). The most significant periods of drought occurred during the years: 1968-1969, 1978-1979, 1989-1994 and 2012-2013. It is clear that the results of both research teams found out that there were cyclical changes of dry and wet periods, which were also graphically demonstrated in this paper.

\section{Conclusion}

The article focused on drought assessment in Slovakia by the PDSI in the period 1957-2016. The results of evaluation on the ten selected sites showed several dry seasons, which appeared on all sites at the same time. These represented different time length during the years 1964, 1973, 1974, 1992, 2000, 2003, 2006, 2007, 2011 and 2012. Despite the occurrence of ten common seasons of drought, we can conclude, that results showed the variability of weather conditions in Slovakia not only in time horizon, but also in spatial distribution. The linear trends on nine sites were decreasing, which means that the aridity of the areas was predominant. The humid trend was detected in Čadca, the most northern site. It was caused by a significant occurrence of very wet and extremely wet months from 2010 to 2016.

\section{References}

DUNKEL, Z. 2009. Brief surveying and discussing of drought indices used in agricultural meteorology. In Időjárás: Quarterly Journal of the Hungarian Meteorological Service, vol. 113, 2009, no. 1-2, pp. 23-37. ISBN 0324-6329. 
EPA. 2016. Climate change indicators in the United States, 2016. $4^{\text {th }}$ ed., EPA 430-R-16-004. www.epa.gov/climate-indicators

FATULOVÁ, E. - MAJERČÁKOVÁ, O. - HOUŠKOVÁ, B. 2015. Globálne vodné partnerstvo pre strednú a východnú Európu. Príručka pre prípravu plánov manažmentu sucha. Vypracovanie a implementácia plánov v kontexte Rámcovej smernice EÚ o vode ako súčast' plánov manažmentu povodí, 2015, 48 pp. ISBN 978-80-972060-0-0.

LITSCHMANN, T. - KLEMENTOVÁ, E. - ROŽNOVSKÝ, J. 2002. Vyhodnoceníperiod sucha v časových řadách pražského Klementina a Hurbanova pomocí PDSI. In ROŽNOVSKÝ, J. - LITSCHMANN, T. (ed.) XIV. Česko-slovenská bioklimatologická konference. Lednice na Moravě, 2. - 4. 9. 2002, pp. 280-289. ISBN 80-85813-99-8. http:// www.cbks.cz/sbornik02/Lit\%2BKlem\%2BRoz.pdf

LITSCHMANN, T. - KLEMENTOVÁ, E. - ROŽNOVSKÝ, J. 2001. PalmerůV index závažnosti sucha a jeho použití v našich podmínkách. Poster in: transport vody, chemikálií a energie v systéme pôda-rastlinaatmosféra, Bratislava, 29. 11. 2001.

MCKEE, T. B. - DOESKEN, N. J. - KLEIST, J. 1993. The relationship of drought frequency and duration to time scales. In Eighth Conference on Applied Climatology, 17.-22. January 1993, Anaheim : American Meteorological Society, pp. 179-184, https://pdfs.semanticscholar. org/c3f7/136d6cb726b295eb34565a8270177c57f40f.pdf

PALMER, W. C. 1965. Meteorologic Drought : Research Paper no. 45, Washington, D.C. : U.S. Weather Bureau, 58 p. https://www.ncdc. noaa.gov/temp-and-precip/drought/docs/palmer.pdf

PATASSIOVÁ, M. - KLEMENTOVÁ, E. - LITSCHMANN, T. - ČISTÝ, M. 2002. Výskyt sucha a analýza zrážok pri jeho výskyte $v$ jarných mesiacoch. In Acta Hydrologica Slovaca, vol. 3, 2002, no. 1, pp. 94101. ISSN 13356291. http://www.amet.cz/vyskytsucha.pdf

SPINONI, J. - NAUMANN, G. - VOGT, J. - BARBOSA, P. 2015. European drought climatologies and trends based on a multi-indicator approach, Global and Planetary Change, vol. 127, 2015, pp. 50-57. ISSN 0921-8181. https://doi.org/10.1016/j.gloplacha.2015.01.012

ŠŤASTNÝ, P. - TURŇA, M. 2013. Manažment sucha - Zhodnotenie rokov 2011 a 2012 podla indexov sucha.
TALL, A. - GOMBOŠ, M. 2011. Aplikácia Palmerovho indexu pre hodnotenie sucha. In SALAŠ, P. (ed) Rostliny v podmínkách měnícího se klimatu. Lednice, 20. - 21. 10. 2011, Úroda, vědecká príloha, 2011, pp. 623-628. ISSN 0139-6013.

VALACH, J. - VIDO, J. - ŠKVARENINA, J. 2014. Zhodnotenie výskytu sucha použitím indexu SPEl v regióne Horného Požitavia. In BRYCH, K. - TESA Ř, M. (eds.): Hydrologie malého povodí 2014. $1^{\text {st }}$ ed., Praha: Ústav pro hydrodynamiku AV ČR, v. v. i. a ČHMÚ, pp. 544-550. ISBN 978-80-02-02526-2 (Ústav pro hydrodynamiku AV ČR, v. v. i.). ISBN 978-80-87577-32-5 (ČHMÚ).

VICENTE-SERRANO, S. M. - BEGUERÍA, S. - LÓPEZ-MORENO, J. I. 2010. A Multiscalar Drought Index Sensitive to Global Warming: The Standardized Precipitation Evapotranspiration Index. In Journal of Climate, vol. 23, 2010, no. 7, pp. 1696-1718. ISSN 1520-0442. DOI: 10.1175/2009JCLI2909.1

VIDO, J. - VALACH, J. - ŠKVARENINA, J. 2014. Zhodnotenie výskytu sucha použitím indexu SPI $v$ regióne Horného Požitavia. In ROŽNOVSKÝ - LITSCHMANN - STŘEDA - STŘEDOVÁ (eds.) Extrémy oběhu vody v krajině. Mikulov, 8. - 9. 4. 2014 [CD]. Praha : ČHMÚ, 2014. ISBN 978-80-87577-30-1.

VINIT K. JAIN - RAJENDRA P. PANDEY - MANOJ K. JAIN HI-RYONG BYUN 2015. Comparison of drought indices for appraisal of drought characteristics in the Ken River Basin, Weather and Climate Extremes, vol. 8, 2015, pp. 1-11. ISSN 2212-0947. https:// doi.org/10.1016/j.wace.2015.05.002

WHITE D. A. 2000. Drought as a natural hazard: concepts and definitions A. Donald, A. Wilhite (Eds.), Drought: A Global Assessment. Routledge, New York, vol. 1, 2000, pp. 3-18.

ŽALUD, Z. -TRNKA, M. - KAPLER, P. - SEMERÁDOVÁ, D. - DUBROVSKÝ, M. 2006. Sucho - problém současnosti i budoucnosti. In Kvasný průmysl, vol. 52, 2006, no. 7-8, pp. 203-234. http://kvasnyprumysl. $\mathrm{cz} / \mathrm{pdfs} / \mathrm{kpr} / 2006 / 07 / 04 . \mathrm{pdf}$ 